\title{
Analisis Pemenuhan Informasi Teknologi Penyuluh Swadaya di Jawa Barat
}

\section{Yoyon Haryanto ${ }^{1}$, Oeng Anwarudin ${ }^{2 *}$}

${ }^{1}$ Jurusan Pertanian, Politeknik Pembangunan Pertanian Bogor, Badan PPSDMP - Kementerian Pertanian Jl. Arya Suryalaga (d/a Cibalagung) No 1 Bogor - Jawa Barat 16001

${ }^{2}$ Jurusan Pertanian, Politeknik Pembangunan Pertanian Manokwari, Badan PPSDMP- Kementerian Pertanian Jl, SPMA Reremi, Manokwari - Papua Barat 98312

\begin{tabular}{l}
\multicolumn{1}{c}{ ARTIKEL INFO } \\
\hline Sejarah artikel \\
Diterima $14 / 10 / 2021$ \\
Diterima dalam bentuk revisi 21/12/2021 \\
Diterima dan disetujui 24/12/2021 \\
Tersedia online 31/12/2021 \\
\hline Kata kunci \\
Informasi \\
Inovasi teknologi \\
Penyuluh swadaya \\
Penyuluhan pertanian \\
\hline
\end{tabular}
\begin{abstract}
ABSTRAK
Penyuluh pertanian swadaya hadir karena adanya tuntutan prinsip partisipasi dalam pembangunan pertanian. Pendekatan ini menempatkan petani sebagai subjek dalam program pembangunan pertanian mulai dari tahap mengidentifikasi masalah, merencanakan, melaksanakan hingga tahap mengevaluasinya. Tujuan dari penelitian ini adalah untuk menganalisis pemenuhan informasi dan inovasi teknologi penyuluh pertanian swadaya dari cara akses serta mengukur dukungan lembaga terkait yang memiliki peranan dalam pemenuhan informasi dan inovasi tersebut. Penelitian dilaksanakan di Jawa Barat. Metode penelitian menggunakan pendekatan survei dengan mengumpulkan data primer secara langsung dari penyuluh swadaya. Sebanyak 244 orang penyuluh swadaya menjadi sampel penelitian dan tersebar di Kabupaten Karawang, Majalengka, Sukabumi, dan Bogor. Pengambilan data dilakukan melalui teknik wawancara menggunakan panduan kuesioner dan observasi di lapangan. Teknis analisis data menggunakan statistik deskriptif dan inferensial. Hasil penelitian menunjukkan bahwa daya akses penyuluh swadaya cukup baik terutama dalam pemenuhan informasi teknologi dari media modern. Pihak perusahaan atau swasta memiliki dukungan yang baik dibandingkan lembaga lainnya yang ada dalam hal pemenuhan informasi teknologi terutama dalam hal informasi sarana prasarana pertanian. Implikasi penelitian ini adalah perlu dukungan lembaga terkait dalam pemenuhan informasi dan teknologi penyuluh pertanian swadaya. Lembaga tersebut adalah lembaga penyuluhan pertanian, pelatihan, pendidikan, penelitian dan perusahaan atau swasta. Pemenuhan informasi tersebut dapat melalui akses teknologi informasi maupun akses sumber informasi konvensional.
\end{abstract}

(C) 2021 Politeknik Pembangunan Pertanian Manokwari 


\section{ABSTRACT}

Self-help agricultural extension workers are present because of the demands of the principle of participation in agricultural development. This approach places farmers as subjects in the agricultural development program starting from the stage of identifying problems, planning, implementing to the stage of evaluating them. The purpose of this research is to analyze the fulfillment of information and technological innovations of selfhelp agricultural extension workers from access methods and to measure the support of related institutions that have a role in fulfilling such information and innovations. The research was conducted in West Java. The research method uses a survey approach by collecting primary data directly from self-help extension workers. A total of 244 selfhelp extension workers became the research sample and were spread across the districts of Karawang, Majalengka, Sukabumi, and Bogor. Data collection

\section{PENDAHULUAN}

Tantangan utama yang dihadapi penyuluhan pertanian saat ini adalah bagaimana mengembangkan pendekatan berkelanjutan dengan pelayanan prima dan memperluas pesan melalui peran kunci agen utama perubahan petani di perdesaan. Marsh \& Pannell (1998) mengungkapkan terkait tantangan penyuluhan saat ini dan masa depan tersebut melalui upayaupaya mengintegrasikan kegiatan penyuluhan pemerintah (public sector) dengan penyuluh swasta (private sector) dan penyuluh swadaya.

Beberapa upaya untuk mengintegrasikan penyuluhan pemerintah (public sector) dengan penyuluh swasta (private sector) dan penyuluh swadaya telah dilakukan. Upaya-upaya tersebut membutuhkan: (1) pengembangan pendidikan, pelatihan dan keprofesionalan untuk sektor publik, (2) menyusun kelembagaan yang efisien dan berkelanjutan untuk meminimumkan biaya was done through interview techniques using a questionnaire guide and field observations. Technical analysis of data using descriptive and inferential statistics. The results showed that the access of self-help extension workers was quite good, especially in fulfilling technological information from modern media. The company or private sector has good support compared to other existing institutions in terms of fulfilling information technology, especially in terms of information on agricultural infrastructure. The implication of this research is that it is necessary to support relevant institutions in fulfilling information and technology for self-help agricultural extension workers. These institutions are agricultural extension, training, education, research and corporate or private institutions. Fulfillment of this information can be through access to information technology or access to conventional information sources.

transaksi, dan (3) membangun struktur kelembagaan yang menjamin keefektifan keterkaitan antara sektor publik dengan swasta dan masyarakat. Pendekatan semacam itu sangat diperlukan untuk meningkatkan pembelajaran dan inovasi petani untuk meningkatkan kapasitas mereka dalam mengorganisir diri agar dapat memproduksi lebih efisien dan pemasaran produk yang kompetitif (David, 2007; Davis et al, 2009; Leeuwis \& van den Ban, 2004).

Paradigma baru penyuluhan memandang bahwa petani merupakan aktor penting dalam mencapai pembangunan yang berkelanjutan, sehingga pendekatan penyuluhan yang digunakan bersifat partisipatif. Pendekatan partisipatif memberikan peran yang tinggi pada petani untuk bersama-sama dengan penyuluh ataupun peneliti untuk mengembangkan program pembangunan mulai dari tahap mengidentifikasi potensi dan masalah, 
merencanakan, melaksanakan sampai dengan tahapan evaluasi. Seiring dengan tuntutan paradigma baru penyuluhan tersebut, penyuluh harus mampu terlibat dan hadir ditengah petani untuk membangun kemandirian petani. Saat ini peranan penyuluh pertanian pemerintah dinilai belum optimal karena ditengarai baru sebatas menyampaikan (diseminator) teknologi dan informasi. Padahal, penyuluh pertanian dituntut dapat berperan menjadi fasilitator, motivator, dinamisator, dan konsultan bagi para petani (Subejo 2009; Tjitropranoto, 2003). Lippitt \& Westley (1958) dan Rogers (2003) menambahkan bahwa penyuluh pertanian wajib memiliki kemampuan menelaah permasalahanpermasalahan yang dihadapi oleh sasaran (petani), membangun dan memelihara hubungan dengan sasaran (petani), mensukseskan terjadinya adopsi dan mencegah berhentinya adopsi.

Petani saat ini membutuhkan penyuluh yang profesional. Penyuluh yang berkualitas adalah pendamping yang setia, ikhlas mentransfer pengetahuannya, dan mau terlibat serta hidup bersama di tengah masyarakat petani (Syahyuti 2016). Sosok penyuluh yang pas dengan kriteria tersebut saat ini ada pada petani maju yang berperan sebagai penyuluh swadaya. Penyuluh swadaya merupakan bagian dari komunitas petani sehingga memiliki rasa empati yang lebih tinggi terutama untuk membantu sesamanya. Sisi keunggulan lainnya dari penyuluh swadaya adalah adanya kepercayaan yang lebih dari komunitasnya (Kiptot \& Franzel 2014; Lukuyu et al. 2012; Samuel 2012). Selain itu, Haryanto et al. (2018) menyatakan bahwa peran yang cukup efektif dijalankan oleh penyuluh swadaya adalah membantu petani dalam memperoleh informasi yang dibutuhkan untuk pengembangan usaha taninya. Namun, selama ini pemenuhan informasi dan inovasi penyuluh swadaya belum teridentifikasi secara jelas asal dan sumbernya meskipun penguasaan akses informasi teknologi dan inovasi mereka cukup baik (Haryanto, 2018).

Pemenuhan kebutuhan informasi penyuluh swadaya tersebut sangat diperlukan dukungan dari berbagai lembaga terkait dalam menyediakan akses baik modern atau pun konvesional. Beberapa lembaga yang terkait dalam penyediaan informasi dan inovasi merupakan bagian dari lembaga yang dapat melakukan pengembangan kapasitas penyuluh swadaya. Namun, selama ini dukungan dari setiap lembaga berbeda baik secara fisik maupun materi. Oleh karena itu, diperlukan analisis tingkat dukungan dari setiap lembaga tersebut terhadap pemenuhan informasi dan inovasi penyuluh swadaya. Berdasarkan hal tersebut, tujuan penelitian ini adalah untuk menganalisis pemenuhan informasi dan inovasi teknologi penyuluh swadaya dari cara akses serta mengukur dukungan lembaga terkait yang memiliki peranan dalam pemenuhan informasi dan inovasi tersebut.

\section{METODE}

Penelitian dilaksanakan di Provinsi Jawa Barat pada Maret sampai dengan Agustus 2020. Penentuan lokasi mempertimbangkan keberagaman kemampuan, kekhasan penyuluh swadaya terutama dari jenis pekerjaan dan kinerja penyuluh swadaya di setiap kabupaten. 
Penelitian menggunakan pendekatan kuantitatif yang didukung dengan data kualitatif. Data kuantitatif diperoleh dengan menggunakan metode survei melalui kuesioner. Kuesioner yang digunakan untuk pengambilan data telah melalui uji validitas dan reliabilitas. Uji validitas dan reliabilitas dilakukan di Kabupaten Cianjur dengan responden adalah penyuluh swadaya sebanyak 30 orang. Hasil uji coba menunjukkan bahwa kuesioner valid dan reliabel untuk digunakan. Nilai uji validitas $0.403-0.872$ dan nilai uji reliabilitas sebesar 0.881 .

Data primer dikumpulkan langsung dari responden penelitian yaitu penyuluh swadaya. Pengambilan data menggunakan teknik wawancara dengan instrumen berupa kuesioner. Teknik lainnya yang digunakan yaitu observasi di lapangan serta wawancara mendalam kepada para petani yang menjadi binaan penyuluh swadaya untuk mengkonfirmasi hasil dari penyuluh swadaya. Data sekunder diperoleh dari dokumentasi data yang sudah tersedia di instansi terkait yang sesuai dengan fokus penelitian.

Sampel ditentukan menggunakan teknik pengambilan sampel cluster random sampling. Lokasi penelitian terpilih adalah empat kabupaten yaitu Karawang, Majalengka, Sukabumi dan Bogor. Penentuan lokasi ini berdasarkan rujukan Sumardjo (1999) yang membagi Jawa Barat menjadi empat zona yaitu Utara, Tengah, Selatan dan Jabotabek. Keempat kabupaten tersebut memiliki populasi berjumlah 482 penyuluh swadaya. Sehubungan dengan cukup besarnya jumlah individu pada populasi tersebut, selanjutnya penentuan sampel menggunakan rumus Slovin dari populasi penyuluh swadaya di empat kabupaten tersebut sehingga diperoleh 224 sampel. Jumlah masing-masing sampel yaitu Bogor 58 orang, Karawang 61 orang, Majalengka 35 orang dan Sukabumi 70 orang. Data yang terkumpul dianalisis menggunakan statistik deskriptif dan inferensial. Perbedaan di empat kabupaten dalam hal pemenuhan informasi inovasi/teknologi dilakukan uji beda menggunakan Duncan Multi Range Test (DMRT).

\section{HASIL DAN PEMBAHASAN}

\section{Pemenuhan Kebutuhan Informasi dan Inovasi Petani Maju}

Secara umum kapasitas penyuluh swadaya perlu ditingkatkan terutama pada aspek mengorganisasikan dan memandirikan petani, meskipun hasil penelitian (Indraningsih, et al. 2016) memberikan informasi bahwa kemampuan penyuluh swadaya relatif beragam, namun penguasaan dari aspek teknis sudah memadai. Selama ini penyuluh swadaya relatif terbatas dalam mengembangkan kapasitasnya, akibatnya beberapa petani yang berada di lingkungan penyuluh swadaya belum merasa terbantu dengan kehadirannya.

Terbatasnya kapasitas penyuluh swadaya, petani memiliki persepsi yang beragam, terutama terkait peran dan kinerjanya. Salah satu persepsi yang muncul di masyarakat tentang penyuluh swadaya adalah perannya sama dengan kontak tani, taruna tani atau tokoh masyarakat. Oleh karena itu peran penyuluh swadaya dalam melakukan kegiatan penyuluhan dan mitra petani belum dapat memberikan dampak yang nyata terhadap 
perubahan perilaku dan peningkatan kesejahteraan petani.

Tokoh atau petani maju sebagai penyuluh swadaya memiliki akses teknologi informasi yang cukup baik. Hal ini membuat penyuluh swadaya mudah dalam mencari inovasi terbaru dan sesuai untuk kebutuhan petani. Namun demikian penyuluh swadaya lemah dalam mengakses sumber informasi konvensional seperti koran, majalah pertanian dan lainnya (Tabel 1). Kondisi ini cukup wajar karena penyuluh swadaya relatif lebih terbuka terhadap teknologi informasi sehingga memudahkan dalam menggunakan perangkat teknologi untuk mengakses sumber inovasi dan informasi terbaru

Tabel 1 Sebaran Penyuluh Swadaya tentang Akses Sumber Informasi untuk Pemenuhan Informasi/Inovasi pada Empat Kabupaten di Jawa Barat

\begin{tabular}{|c|c|c|c|c|c|}
\hline \multirow{3}{*}{ No } & \multirow{3}{*}{$\begin{array}{c}\text { Pemenuhan Informasi Inovasi/ } \\
\text { Kategori (Skor) }\end{array}$} & \multicolumn{4}{|c|}{ Kabupaten } \\
\hline & & $\begin{array}{l}\text { Bogor } \\
(n=58)\end{array}$ & $\begin{array}{c}\text { Karawang } \\
(n=61)\end{array}$ & $\begin{array}{c}\text { Majalengka } \\
(\mathbf{n}=35)\end{array}$ & $\begin{array}{c}\text { Sukabumi } \\
(\mathbf{n}=70)\end{array}$ \\
\hline & & $\%$ & $\%$ & $\%$ & $\%$ \\
\hline \multirow[t]{6}{*}{1} & Akses Teknologi Informasi & & & & \\
\hline & Sangat Rendah & 0.0 & 18.0 & 14.3 & 0.0 \\
\hline & Rendah & 31.0 & 44.3 & 28.6 & 40.0 \\
\hline & Sedang & 46.6 & 36.1 & 37.1 & 60.0 \\
\hline & Tinggi & 22.4 & 1.6 & 20.0 & 0.0 \\
\hline & Rataan (Skor) & $58.1^{a}$ & $53.0^{\mathrm{a}}$ & $52.8^{a}$ & $53.1^{\mathrm{a}}$ \\
\hline \multirow[t]{6}{*}{2} & $\begin{array}{l}\text { Akses Sumber Informasi } \\
\text { Konvensional }\end{array}$ & & & & \\
\hline & Sangat Rendah & 43.1 & 29.5 & 14.3 & 4.3 \\
\hline & Rendah & 41.4 & 31.1 & 65.7 & 81.4 \\
\hline & Sedang & 15.5 & 32.8 & 14.3 & 12.9 \\
\hline & Tinggi & 0.0 & 6.6 & 5.7 & 1.4 \\
\hline & Rataan (Skor) & $25.4^{\mathrm{a}}$ & $39.6^{b}$ & $40.3^{b}$ & $43.8^{b}$ \\
\hline
\end{tabular}

Keterangan skor Indeks: Sangat rendah $\leq 25$; Rendah 26-50; Sedang 51-75; Tinggi $\geq 76$

* Rataan yang diikuti oleh huruf yang sama tidak berbeda nyata $(\alpha: 0.05)$ berdasarkan Uji Beda dengan Duncan Multi Range Test (DMRT) 
Sebagian besar penyuluh swadaya menilai hal yang melatarbelakangi rendahnya akses terhadap media konvensional adalah dari aspek ketersediaan media konvensional itu sendiri. Hal ini bermakna bahwa ketersediaan media konvensional belum optimal dalam meningkatkan kapasitas penyuluh swadaya. Media sumber informasi konvensional yang sering menjadi rujukkan sumber informasi penyuluh swadaya adalah leaflet/brosur dan majalah cetak pertanian.

Informasi dan inovasi dari sumber teknologi yang begitu pesat di sektor pertanian belakangan ini memberikan dampak positif terhadap perkembangan usaha tani di perdesaan. Namun demikian semua informasi inovasi tersebut belum mampu memberikan kontribusi yang nyata dalam peningkatan kemandirian petani. Hal tersebut terlihat dari masih tergantungnya petani terhadap sumber informasi secara konvensional dari penyuluh. Momentum ini menjadi sangat bermakna ketika informasi inovasi tersebut diperolehnya dari penyuluh swadaya, karena petani lebih mempercayai yang dikomunikasikan oleh penyuluh swadaya dibandingkan dengan memperoleh sumber informasi dari yang lainnya. Informasi ini menunjukkan hal yang sama dengan penelitian yang telah dilakukan sebelumnya (Anwarudin \& Haryanto, 2016; Haryanto \& Yuniarti, 2017; Anwarudin \& Haryanto, 2018; Haryanto, 2018; Haryanto et al. 2018b).

Kehadiran penyuluh swadaya dirasakan oleh petani. Kesulitan mengakses informasi oleh petani selama ini mempengaruhi pengetahuan petani. Keterbatasan berbagai informasi menyebabkan tingkat adopsi rendah. Hal ini dapat diselesaikan dengan hadirnya penyuluh swadaya. Penyuluh swadaya mampu mengakses sumber informasi teknologi sehingga dapat memperoleh informasi dan inovasi terbaru serta memilih yang sesuai dengan kebutuhan petani. Akses informasi dari penyuluh, peneliti, dan media massa (radio, internet, televisi, koran/majalah) lebih sulit diperoleh dibandingkan dengan akses ke sesama petani, ketua kelompok tani, maupun pedagang sarana produksi pertanian (Fatchiya A, 2010; Anwarudin et al., 2020). Indraningsih et al. (2010) menyatakan sumber informasi utama umumnya diperoleh dari sesama petani dan atau dari ketua kelompok tani atau Gabungan Kelompok Tani (Gapoktan).

Hal tersebut menegaskan meskipun semakin meningkatnya perkembangan ilmu pengetahuan dan teknologi tetapi peran penyuluh swadaya sebagai penyedia layanan informasi inovasi penyuluhan masih relevan dan dibutuhkan oleh petani. Sehubungan dengan hal tersebut, diperlukan dukungan dari pemerintah untuk meningkatkan kemampuan penyuluh swadaya dalam mengakses berbagai sumber informasi sehingga penyuluh swadaya memiliki kemampuan yang tinggi dalam menyebarluaskan informasi inovasi kepada petani di komunitasnya.

Kehadiran penyuluh swadaya pada komunitasnya dapat memberikan solusi kepada petani terutama dalam mengkases informasi yang dibutuhkan. Kondisi ini sejalan dengan penelitian Oktavia et al. (2017) bahwa petani memiliki kecenderungan dalam mengakses dan membagikan informasi melalui saluran 
interpersonal, yaitu antara penyuluh swadaya dengan petani. Oleh karena itu, penyuluh swadaya memiliki potensi menjadi alternatif penyelesaian masalah dari kurangnya ketenagaan penyuluhan saat ini. Hal ini juga mencerminkan bahwa pemberi informasi terutama yang berasal dari penyuluh swadaya memiliki interaksi dengan petani lebih intensif, lebih mudah melayani dan memberikan informasi serta bersikap baik. Hasil penelitian Ruhimat (2014) memperlihatkan juga bahwa tingkat ketersediaan informasi yang rendah ditandai dengan ketepatan waktu informasi, relevansi informasi dan kemudahan mendapatkan informasi yang disediakan oleh penyuluh. Mengkonfirmasi hasil dengan penelitian terdahulu memperlihatkan adanya kesamaan makna, yang berarti penyuluh swadaya memiliki peran sentral dalam penyediaan informasi inovasi bagi petani di sekitarnya.

Hasil uji beda di empat kabupaten memperlihatkan bahwa tidak terdapat perbedaan penyuluh swadaya dalam mengakses teknologi informasi. Namun demikian untuk akses sumber informasi konvensional hanya penyuluh swadaya dari Kabupaten Bogor yang berbeda nyata dengan penyuluh swadaya di tiga kabupaten lainnya. Hal ini menandakan bahwa penyuluh swadaya memiliki kemampuan yang relatif sama dalam mengakses berbagai sumber informasi khususnya teknologi informasi, tetapi berbeda dalam pemanfaatannya karena kecenderungan penyuluh swadaya di Kabupaten Bogor telah mampu memanfaatkan sumber teknologi informasi untuk mengembangkan usahanya sehingga ketergantungan terhadap sumber informasi konvensional relatif rendah dengan penyuluh swadaya di tiga kabupaten lainnya yang masih cukup tergantung dengan sumber informasi konvensional.

Pemanfaatan teknologi informasi menjadi pembeda antara penyuluh swadaya di Kabupaten Bogor dengan yang lainnya. Hal ini dapat menegaskan bahwa ternyata dalam praktiknya tidak semua penyuluh swadaya dapat menggunakan akses teknologi dan informasi untuk kepentingan usaha dan petani, serta masih memiliki kecenderungan tergantung dengan sumber informasi yang sifatnya konvensional terutama untuk penyuluh swadaya yang memiliki usia diatas 40 tahun dan berpendidikan formal rendah. Hal ini sesuai dengan hasil penelitian Batte et al. (1990) dan Warren et al. (2016) menyatakan bahwa pemanfaatan teknologi informasi dan komunikasi sangat terkait dengan umur, tingkat pendidikan, jenis dan ukuran (skala) usahanya. Penyuluh swadaya yang mampu mengakses dan menyaring informasi dan inovasi terlihat dari tindakannya dalam mengelola informasi tersebut menjadi lebih seimbang dan beragam terutama ketika memadukannya dengan budaya lokal yang ada di masyarakat. Penyuluh swadaya di Kabupaten Bogor terlihat menonjol dibandingkan dengan penyuluh swadaya yang ada di lokasi penelitian lainnya. Hal ini karena, aksesnya yang mudah dengan sumber-sumber informasi dan inovasi baik perguruan tinggi, lembaga penelitian, lembaga penyuluhan pusat maupun dengan pihak swasta. Khusus dengan pihak swasta mereka sering terlihat berkolaborasi 
memberikan contoh kepada petani di sekitarnya dalam hal pengembangan usaha tani menggunakan produk-produk baru yang dihasilkan oleh perusahaan penyedia sarana produksi pertanian.

Hal lain yang menyebabkan masih rendahnya penyuluh swadaya di Kabupaten Majalengka, Karawang dan Sukabumi dalam mengakses sumber informasi teknologi adalah terbatasnya kemampuan yang dimiliki terutama dalam penggunaan alat teknologinya. Selain itu, sebagian besar penyuluh swadaya tidak serta merta mampu mengakses sumber informasi teknologi tersebut juga disebabkan: (1) jangkauan layanan teknologi informasi masih terbatas; (2) penyuluh swadaya belum menganggap penting dengan ketersediaan informasi tersebut; dan (3) minimnya bimbingan dan pelatihan dari narasumber yang terkait cara mengakses informasi teknologi.

Penyuluh swadaya di Kabupaten Sukabumi memiliki akses sumber informasi konvensional relatif lebih baik. Hasil pengamatan memperlihatkan bahwa penyuluh swadaya meskipun seorang petani pembelajar namun untuk meluangkan waktu membaca atau sekedar mendengarkan radio atau melihat televisi yang berkaitan dengan perkembangan pertanian relatif masih kurang. Mereka lebih suka memperoleh informasi dan inovasi tersebut secara langsung dari sumber utamanya yaitu dari peneliti, penyuluh pemerintah atau dosen. Oleh karena itu, dukungan lembaga penyuluhan, penelitian dan pendidikan perlu dioptimalkan agar penyuluh swadaya memperoleh inovasi yang dapat mengembangkan usaha taninya sehingga dapat ditularkannya kepada petani lainnya di komunitasnya. Ujung dari hal tersebut adalah kemandirian baik penyuluh swadaya maupun petani.

\section{Dukungan Lembaga dalam Pemenuhan Informasi Teknologi}

Dukungan lembaga baik dari sektor pemerintahan, swasta, masyarakat dan keluarga merupakan salah satu hal agar proses penyelenggaraan penyuluhan dapat berjalan dengan efektif (Sumardjo 1999). Menurut Valera et al. (1987), bahwa fungsi penyuluhan dapat dapat dilihat dari dinamika dan proses dalam struktur sistem yang selanjutnya terbagi dalam tiga komponen utama yaitu subsistem penelitian, subsistem perubahan dan subsistem klien. Ketiga komponen sistem ini saling terkait satu sama lain sehingga menciptakan siklus yang saling berhubungan satu sama lainnya dalam menciptakan dan membangun masyarakat pertanian menuju peningkatan kualitas hidup yang lebih baik dan meningkatkan ketertinggalan serta kemiskinan di perdesaan.

Keterkaitan paradigma sistem kerjasama penelitian penyuluhan pertanian telah diungkapkan oleh Valera et al. (1987). Terlepas adanya perbedaan dalam setiap organisasi yang telibat dalam kegiatan penyuluhan baik peneliti, penyuluh atau petani itu sendiri namun pada dasarnya ketiga komponen utama tersebut telah melekat sebagai suatu sistem. Komponen sistem tersebut adalah subsistem penelitian, subsistem perubahan dan subsistem klien. Ketiganya tidak dapat dipisahkan dalam mewujudkan perubahan menjadi kondisi yang lebih baik. Subsistem penelitian adalah suatu 
kegiatan untuk menghasilkan ilmu dan teknologi yang dapat digunakan oleh penerima manfaat dalam hal ini petani. Inovasi yang dihasilkan merupakan teknologi yang tepat guna yang adaptif dengan kondisi masyarakat lokal. (kebiasaan, ekonomi, pengetahuan, pendidikan, tujuan dan nilai-nilai budaya). Subsistem ini merupakan permulaan dari sebuah teknologi diciptakan yang kemudian menjadi dasar dalam perubahan dan perkembangan kondisi masyarakat tersebut. Peneliti mempunyai peran yang sangat besar dalam sistem ini.

Subsistem perubahan merupakan subsistem yang kegiatan-kegiatannya mengarah pada transformasi sistem sosial terutama dalam difusi teknologi. Subsistem ini adalah dogma, kerja keras, pengorganisasian, kelembagaan, struktur organisasi, program, pendekatan, metode atau teknik, media, materi, program pemberdayaan dan agen perubah. Pendekatan penyuluhan yang diorganisasikan merupakan perpaduan dan kombinasi strategis dari metode, materi dan media di dalam penyuluhan pedesaan di suatu wilayah tertentu. Antara pendekatan yang satu dengan pendekatan lainnya saling terintegrasi dan tidak berdiri sendiri.

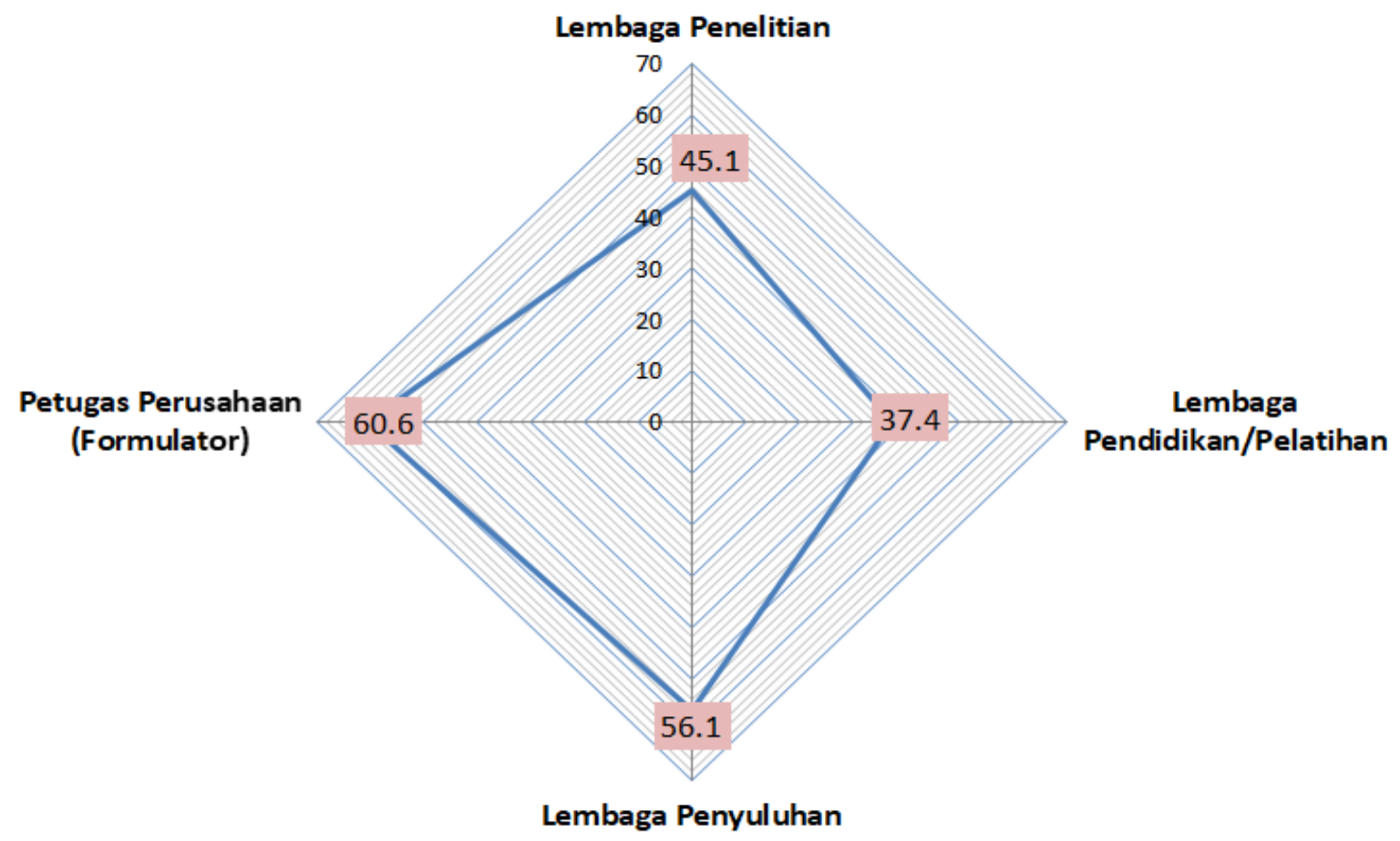

Gambar 1. Tingkat dukungan lembaga terkait terhadap penyuluh swadaya

Subsistem klien dapat sebagai petani,

kelompok, komunitas dan masyarakat desa yang merupakan bagian dari sistem penyuluhan. Di dalam konteks penyuluhan, klien merupakan pelaku utama dalam pembangunan pertanian. Klien adalah penerima manfaat dari informasi inovasi teknologi sesuai kebutuhannya. Informasi tersebut diperoleh dengan memanfaatkan saluran komunikasi yang ada. Dengan demikian esensi dari sistem 
penyuluhan adalah mekanisme difusi teknologi. Diseminasi dari inovasi teknologi akan sukses apabila ada kerjasama dan koordinasi dari semua pihak yang menjadi komponen sistem. Sehubungan dengan hal ini pemerintah harus dapat berperan sebagai regulator. Pemerintah harus mampu mendorong terciptanya sinergisitas ketiga subsistem ini bekerja sebagai satu sistem sehingga ujung tujuan dari siklus sistem ini dapat tercapai yaitu meningkatnya kualitas hidup masyarakat di pedesaan.

Dukungan lembaga penelitian, penyuluhan, dan pendidikan pelatihan yang dimiliki oleh Kementerian Pertanian khususnya terhadap penyuluh swadaya memperlihatkan bahwa di keempat lokasi penelitian relatif sama (Gambar 1). Khusus untuk dukungan pihak swasta yang diberikan kepada penyuluh swadaya relatif berbeda di keempat kabupaten. Hal tersebut memperlihatkan bahwa penyuluh swasta yang berada di keempat kabupaten mampu menciptakan suasana kekeluagaan yang baik dengan penyuluh swadaya terutama dalam membantu memenuhi kebutuhan petani di perdesaan dalam hal ini adalah sarana prasarana usaha tani. Kecenderungan tersebut juga perlu menjadi perhatian dari pemerintah agar peran lembaga penelitian, penyuluhan dan pendidikan pelatihan ditingkatkan dalam melakukan pemberdayaan kepada penyuluh swadaya dan petani disekitarnya.

Lembaga penyuluhan pemerintah dan pihak swasta memperlihatkan dukungan yang lebih baik dibandingkan dengan lembaga penelitian dan pendidikan terkait penyuluh swadaya. Pemerintah telah mendorong penyuluh swadaya memiliki pondasi yang kuat sebagai orang yang dapat membantu mengatasi permasalahan petani (Gambar 1). Kondisi saat ini kelembagaan penyuluhan di empat kabupaten lokasi penelitian mengalami perubahan nomenklatur yang menyebabkan berkurangnya dukungan terhadap penyuluh swadaya. Hal tersebut juga menegaskan terjadinya gelombang pasang perubahan nomenkaltur sebagai akibat pemberlakuan Undang-Undang No 23 tahun 2014 tentang Pemerintah Daerah yang merubah kelembagaan penyuluhan di tingkat kabupaten khususnya.

Kelembagaan penyuluhan mengalami pasang surut karena adanya regulasi yang terus berubah. Dinamika perubahan ini juga secara tidak langsung berpengaruh terhadap peran penyuluh swadaya dalam memberdayakan petani dan upaya pembaruan generasi petani yang cenderung lambat di negeri ini. Hasil penelitian memperlihatkan bahwa nilai eksistensi kelembagaan penyuluhan di Kabupaten Bogor dan Sukabumi relatif baik dibandingkan dengan Kabupaten Karawang dan Majalengka meskipun kelembagaan penyuluhan menjadi bagian kelembagaan teknis yang cenderung pada kegiatan proyek pemerintah daerah, sehingga dampaknya juga dirasakan oleh penyuluh swadaya seperti berkurangnya kegiatan penyuluhan, pembelajaran dan pengujian teknologi.

Hasil pengamatan di lapangan, dengan bergabungnya kelembagaan penyuluhan ke dinas teknis memiliki hal yang positif dan negatif. Hal positif adalah koordinasi antara penyuluh pertanian sebagai pelaksana di lapangan menjadi relatif lebih baik karena satu arah (instruksi) dan memotong jalur birokrasi 
yang selama hadirnya kelembagaan penyuluhan menjadi ego sektoral tersendiri. Sementara hal negatifnya adalah kegiatan penyuluhan lebih cenderung menjadi tidak prioritas untuk meningkatkan kapasitas petani tetapi lebih pada untuk menjalankan kegiatan dinas. Kondisi yang terjadi dengan kelembagaan penyuluhan saat ini tersebut, diharapkan tetap menjadi wadah untuk upaya meremajakan para petani kita dan memberikan daya tarik tersendiri terhadap petani muda untuk berkiprah lebih jauh di sektor pertanian dan penyuluh swadaya tetap memperoleh perhatian dalam menyelenggarakan penyuluhan dari petani ke petani.

Lembaga penelitian, pendidikan dan penyuluhan harus lebih banyak memberi kesempatan kepada penyuluh swadaya dan petani untuk berpartisipasi pada kegiatan pengujian teknologi dan temu lapang. Tindak lanjutnya adalah memberikan kesempatan penyuluh swadaya dan petani untuk memaparkan hasil pengujiannya (bukan oleh peneliti). Lembaga penelitian juga perlu menghasilkan teknologi praktis (hasil kemas ulang penelitian yang bersifat ilmiah) yang disebarluaskan dan diakses melalui teknologi informasi.

\section{KESIMPULAN}

Berdasarkan hasil penelitian, tokoh petani maju sebagai penyuluh swadaya memiliki akses teknologi informasi yang cukup baik. Hal ini mempermudah dalam mencari inovasi melalui media modern dan menyampaikannya kembali kepada sesama petani di wilayahnya. Namun, hal tersebut juga berimbas pada lemahnya kemampuan dari petani maju untuk mengakses sumber informasi konvensional. Lembaga yang dominan memberikan dukungan dalam pemenuhan informasi teknologi petani maju adalah lembaga swasta (perusahaan), terutama dalam hal pemenuhan informasi sarana usaha pertanian.

\section{DAFTAR PUSTAKA}

Anwarudin, O., \& Haryanto, Y. (2016). Peran penyuluh pertanian swadaya dalam memotivasi generasi muda pelaku pertanian. Bogor.

Anwarudin, O., \& Haryanto, Y. (2018). The role of farmer-to-farmer extension as a motivator for the agriculture young generation. International Journal of Social Science and Economic Research (IJSSER). 3(1): 428-437.

Anwarudin, O., Sumardjo, S., Satria, A., \& Fatchiya, A. 2020. Kapasitas kewirausahaan petani muda dalam agribisnis di Jawa Barat. Jurnal Penyuluhan. 16(2): 267-276.

Batte, M. T., Jones, E., \& Schnitkey, G. D. (1990). Computer Use by Ohio Commercial Farmers. American Journal of Agricultural Economics, 72(4), 935945.

David S. (2007). Learning to Think for Ourselves: Knowledge Improvement and Social Benefits among Farmer Field School Participants in Cameroon. Journal of International Agricultural and Extension Education, 14(2), 35-49.

Davis, K., Faure, G., Nahdy, M. S., \& Chipeta, S. (2009). Institutional changes and challenges for agricultural advisory services in Africa. Theory and practice of advisory work in a time of turbulences. XIX European Seminar on Extension Education, 15-19 September 2009, Assisi, Italy.

Fatchiya A. (2010). Tingkat Kapasitas Pembudidaya Ikan dalam Mengelola 
Usaha Aquakultur secara Berkelanjutan. Penyuluhan, 6(1), 11-18.

Haryanto, Y. (2018). Penguatan Kapasitas dan Kemandirian Tokoh Petani Maju sebagai Penyuluh Swadaya. IPB.

Haryanto, Y., Sumardjo, S., Amanah, S., \& Tjitropranoto, P. (2018a). Efektivitas Peran Penyuluh Swadaya dalam Pemberdayaan Petani di Jawa Barat. Jurnal Pengkajian dan Pengembangan Teknologi Pertanian, 20(2), 142-154.

Haryanto, Y., Sumardjo, S., Amanah, S., \& Tjitropranoto, P. (2018b). Farmer to Farmer Extension Through Strengthening Progressive Farmers Role. International Journal of Progressive Sciences and Technologies (IJPSAT), 6(2), 228-234.

Haryanto, Y., \& Yuniarti, W. (2017). The Role of Farmer to Farmer Extension for Rice Farmer Independence in Bogor. International Journal of Research in Social Sciences, 7(4), 62-74.

Indraningsih, K. S., Sugihen, B. G., Tjitropranoto, P., Pertanian, P. P., \& Mengingat, K. (2010). Performance of Extension Workers from Farmer ' $\mathrm{s}$ Perspective and The Existence of SelfSupport Extension Agents as Counterpart of Agricultural Extension Workers. Analisis Kebijakan Pertanian, 8(1), 303321.

Indraningsih, K. S., Sugihen, B., Tjitrpranoto, P., Asngari, P., \& Wijayanto, H. (2016). Kinerja Penyuluh dari Perspektif Petani dan Eksistensi Penyuluh Swadaya Sebagai Pendamping Penyuluh Pertanian. Analisis Kebijakan Pertanian, 8(4), 303321.

Kerlinger F.N. (2004). Asas-asas Penelitian Behavioral (Ketiga). Yogyakarta (ID): Gadjah Mada University Press.

Kiptot, E., \& Franzel, S. (2014). Voluntarism as an investment in human, social and financial capital: Evidence from a farmerto-farmer extension program in Kenya. Agriculture and Human Values.

Leeuwis C. \& van den Ban. (2004). Communication for Rural Innovation.
Rethinking Agricultural Extension 3rd ed. Oxford (UK): Blackwell Publishing.

Lippitt. (1958). Planned Change: A Comparative Study of Principles and Techniques. New York (US): Harcourt, Brace \& World, Inc.

Lukuyu, B., Place, F., Franzel, S., \& Kiptot, E. (2012). Disseminating Improved Practices: Are Volunteer Farmer Trainers Effective? Journal of Agricultural Education and Extension.

Marsh, S., \& Pannell, D. (1998). The changing relationship between private and public sector agricultural extension in Australia. Rural Society, 8(2), 133-151.

Oktavia, Y., Muljono, P., Amanah, S., \& Hubeis, M. (2017). Jurnal Penyuluhan, September 2017 Vol. 13 No. 2 Hubungan Perilaku Komunikasi dan Pengembangan Kapasitas Pelaku Agribisnis Perikanan Air Tawar di Padang, Sumatera Barat. Jurnal Penyuluhan, 13(2), 157-165.

Rogers, E. . (2003). Diffusion of Innovations. Fifth Edition. New York (US): The Free Press.

Ruhimat S. (2014). Faktor-Faktor Untuk Peningkatan Kemandirian Petani Dalam Pengelolaan Hutan Rakyat: Studi Kasus Di Desa Ranggang, Kabupaten Tanah Laut, Kalimantan Selatan. Jurnal Penelitian Sosial dan Ekonomi Kehutanan, 11(3), 237-249.

Samuel ZB, K. A. and G. J. (2012). Promoting community-based extension agents as an alternative approach to formal agricultural extension service delivery in Northern Ghana. Asian Journal of Agriculture and Rural Development, 2(1), 76-95.

Subejo. (2009). Revolusi Hijau dan Penyuluhan Pertanian. Tokyo: Indonesian Agricultural Sciences Association. Diambil dari www.iasa-pusat.org/artikel/revolusihijaudan-penyuluhan-pertanian.html

Sumardjo. (1999). Transformasi model penyuluhan pertanian menuju pengembangan kemandirian petani (Kasus di Propinsi Jawa Barat) [disertasi]. 1-372. 
Syahyuti, N. (2016). Peran Strategis Penyuluh Swadaya dalam Paradigma Baru Penyuluhan Pertanian Indonesia. Forum penelitian Agro Ekonomi, 32(1), 43.

Tjitropranoto, P. (2003). Penyuluh Pertanian: Masa Kini dan Masa Depan. In Membentuk Pola Perilaku Manusia Pembangunan. Bogor (ID): IPB.

Valera JB, VIcente A, Marinez, P. R. (1987). an Extension Delivery System. Manila: Island Publishing House Inc.

Warren, C. R., Burton, R., Buchanan, O., \& Birnie, R. V. (2016). Limited adoption of short rotation coppice: The role of farmers' socio-cultural identity in influencing practice. Journal of Rural Studies, 45, 175-183. 